\title{
Recovery of Alkaline Earth Metals from Desalination Brine for Carbon Capture and Sodium Removal
}

\author{
Cheng-Han Lee ${ }^{1}$ (D) Pin-Han Chen ${ }^{2}$ and Wei-Sheng Chen ${ }^{1, *(D)}$ \\ 1 Department of Resources Engineering, National Cheng Kung University, No. 1, Daxue Rd., East Dist., \\ Tainan City 70101, Taiwan; n48091013@gs.ncku.edu.tw \\ 2 Tainan Hydraulics Laboratory, National Cheng Kung University, No. 500, Sec. 3, Anming Rd., Annan Dist., \\ Tainan City 709015, Taiwan; hannah83530@thl.ncku.edu.tw \\ * Correspondence: kenchen@mail.ncku.edu.tw; Tel.: +886-6-2757575 (ext. 62828)
}

check for updates

Citation: Lee, C.-H.; Chen, P.-H.;

Chen, W.-S. Recovery of Alkaline Earth Metals from Desalination Brine for Carbon Capture and Sodium Removal. Water 2021, 13, 3463. https://doi.org/10.3390/w13233463

Academic Editor: Thomas M. Missimer

Received: 5 November 2021

Accepted: 3 December 2021

Published: 6 December 2021

Publisher's Note: MDPI stays neutral with regard to jurisdictional claims in published maps and institutional affiliations.

Copyright: (C) 2021 by the authors Licensee MDPI, Basel, Switzerland. This article is an open access article distributed under the terms and conditions of the Creative Commons Attribution (CC BY) license (https:// creativecommons.org/licenses/by/ $4.0 /)$.

\begin{abstract}
Because carbon dioxide adsorbs the radiation from the Sun and the Earth's surface, global warming has become a severe problem in this century. Global warming causes many environmental problems such as heatwave, desertification, and erratic rainfall. Above all, erratic rainfall makes people have insufficient freshwater. To solve this problem, desalination technology has been developed in many countries. Although desalination technology can provide freshwater, it produces brine as well (producing $1 \mathrm{~L}$ of freshwater would result in $1 \mathrm{~L}$ of brine). The brine will decrease the dissolved oxygen in the sea and affect the organism's habitat. In this study, magnesium and calcium from desalination brine were recovered in the form of magnesium hydroxide and calcium hydroxide by adjusting the $\mathrm{pH}$ value for carbon capture and sodium removal. Magnesium hydroxide would turn into magnesium carbonate through contacting $\mathrm{CO}_{2}$ in saturated amine carriers. Calcium hydroxide was added to the brine and reacted with $\mathrm{CO}_{2}$ (modified Solvay process). Sodium in brine would then be precipitated in the form of sodium bicarbonate. After removing sodium, brine can be released back into the ocean, or other valuable metals can be extracted from brine without the side effect of sodium. The results revealed that $288 \mathrm{~K}$ of 3-Amino-1-propanol could capture $15 \mathrm{~L}$ ( $26.9 \mathrm{~g}$ ) of $\mathrm{CO}_{2}$ and that $25 \mathrm{~g} / \mathrm{L}$ of $\mathrm{Ca}(\mathrm{OH})_{2}$ at $288 \mathrm{~K}$ was the optimal parameter to remove $7000 \mathrm{ppm}$ sodium and adsorb $16 \mathrm{~L}\left(28.7 \mathrm{~g}\right.$ ) of $\mathrm{CO}_{2}$ in the modified Solvay process. In a nutshell, this research aims to simultaneously treat the issue of $\mathrm{CO}_{2}$ emission and desalination brine by combining the amines carrier method and the modified Solvay process.
\end{abstract}

Keywords: recovery; desalination brine; amine carrier; modified Solvay process; carbon capture; sodium removal; magnesium; calcium

\section{Introduction}

Carbon dioxide $\left(\mathrm{CO}_{2}\right)$ is the principal reason for the greenhouse effect, global warming, and climate change [1-5]. The global average temperature increases when the concentration of $\mathrm{CO}_{2}$ rises and causes many extreme climate events such as heatwave, desertification, and erratic rainfall. Among them, erratic rainfall makes people have insufficient freshwater. According to a survey of the United Nations (UN), more than 1 billion people in the world will live in areas with scarce water resources by 2025 [6]. To solve the problem, desalination technology has been developed since the 1950s [7]. However, when desalination technology is ordinary, the by-product of desalination, brine, also brings about considerable harm to the environment. For example, the brine will decrease the dissolved oxygen in the sea and affect the organism's habitat. Besides, producing $1 \mathrm{~L}$ of freshwater will generate $1 \mathrm{~L}$ of brine, demonstrating that the amount of brine from desalination plants is equal to freshwater. To solve these problems simultaneously, brine is used for $\mathrm{CO}_{2}$ capture to enhance its value (Avoiding releasing it directly into the ocean).

Carbon capture and utilization (CCU) can be mainly divided into organic CCU and inorganic CCU [8-10]. In organic CCU, the processes require a high temperature, pressure, 
and catalysts to produce valuable organic compounds; therefore, this requires much money in order to reach the goal of industrialization and commercialization. In inorganic CCU, the energy consumption is much lower than organic CCU due to the lower temperature and pressure during the processes. It can also use many materials such as amine [11], ammonia [12-15], alkaline materials [16], solid wastes [17-22], fly ash [23-26], cement [27], wastewater [28,29], and brine to capture $\mathrm{CO}_{2}$ [30-32]. In the inorganic $\mathrm{CCU}$ method, magnesium and calcium are the chief elements for capturing $\mathrm{CO}_{2}$ due to their high reaction with $\mathrm{CO}_{2}$ and their obtainability. $\mathrm{CO}_{2}$ can be absorbed and turned into magnesium carbonate and calcium carbonate, which will be utilized in coating materials, food additives, and medicines. Due to the importance of magnesium and calcium, some research has suggested separating them from desalination brine and using them to capture $\mathrm{CO}_{2}$ through the amine carrier method and the modified Solvay process [33-36]. The outputs of previous research are shown in Table 1.

Table 1. The outputs of previous research.

\begin{tabular}{|c|c|c|}
\hline Author & Method & Process and Results \\
\hline D. Kang et al. [33] & Amine carrier method & $\begin{array}{l}0.79,0.34 \text { and } 0.19 \text { mol of } \mathrm{CO}_{2} \text { was captured by } 5,10 \text { and } 30 \mathrm{wt} \% \\
\text { of aqueous MEA solutions, separately. When pretreated brine } \\
\text { solutions were added to each saturated MEA solution, } \mathrm{CO}_{2} \text { was } \\
\text { turned into } \mathrm{CaCO}_{3} \text {. Through analyses, it was proven that the } \\
\mathrm{CaCO}_{3} \text { was in the form of calcite. }\end{array}$ \\
\hline Y. Yoo et al. [34] & Amine carrier method & $\begin{array}{l}\mathrm{CO}_{2} \text { was captured by different amines and carried into the } \\
\text { separated } \mathrm{Ca}(\mathrm{OH})_{2} \text { to generate } \mathrm{CaCO}_{3} \text {. XRD, SEM, FT-IR and } \\
\text { TG/DTG analyses were used to investigate the crystal shape, } \\
\text { polymorph, and purity of the product. The results illustrated that } \\
\text { crystallization inhibition was possible, depending on the } \\
\text { structural properties of amine carriers, leading to a successful } \\
\qquad \mathrm{CaCO}_{3} \text { polymorph control. }\end{array}$ \\
\hline M.H. El-Naas et al. [36] & Modified Solvay process & $\begin{array}{l}\text { The authors replaced ammonia with calcium oxide to conduct a } \\
\mathrm{CO}_{2} \text { capture. In this modified Solvay process, each mole of } \\
\mathrm{Ca}(\mathrm{OH})_{2} \text { could capture two moles of } \mathrm{CO}_{2} \text {. Moreover, calcium } \\
\text { hydroxide could be directly obtained from brine by adjusting the } \\
\text { pH value. Under the optimal conditions, a } \mathrm{CO}_{2} \text { capture of } 86 \% \\
\text { and } 99 \% \text { and sodium removal of } 29 \% \text { and } 35 \% \text { were achieved for } \\
\text { the traditional Solvay and the modified process, respectively. }\end{array}$ \\
\hline
\end{tabular}

The Amine carrier method uses amine to adsorb $\mathrm{CO}_{2}$ first, and alkaline earth metals can react with the saturated amines to form bicarbonate solutions or carbonate compounds. Since the magnesium and calcium in the brine are abundant, brine can be applied to this method. The $\mathrm{pH}$ value of brine can be adjusted to a strong base to precipitate magnesium hydroxide and calcium hydroxide for a reaction with amines. The merits of this process are that it does not need too much energy consumption and can produce valuable products. The other method, the modified Solvay process, is the improvement of the Solvay process. The Solvay process is the primary industrial process for producing sodium carbonate, and the ingredients for this are salt and limestone. The Solvay process is related to desalination brine and $\mathrm{CO}_{2}$ capture because salt can be collected from brine, and it can react with $\mathrm{CO}_{2}$, $\mathrm{H}_{2} \mathrm{O}$, and $\mathrm{NH}_{3}$ to generate sodium bicarbonate and ammonium chloride (Equation (1)). Although this process is inexpensive and convenient, ammonia volatilizes easily and is harmful to humans [37]. In this case, calcium hydroxide from desalination brine replaces ammonia to decrease the danger in the process (Equation (2)) [36]. The other advantage of calcium hydroxide is that it can increase the $\mathrm{pH}$ value of the system so that the $\mathrm{CO}_{2}$ can be adsorbed more than the ammonia system. 


$$
\begin{aligned}
& \mathrm{NaCl}+\mathrm{CO}_{2}+\mathrm{NH}_{3}+\mathrm{H}_{2} \mathrm{O} \rightarrow \mathrm{NaHCO}_{3}+\mathrm{NH}_{4} \mathrm{Cl} \\
& 2 \mathrm{NaCl}+2 \mathrm{CO}_{2}+\mathrm{Ca}(\mathrm{OH})_{2} \rightarrow 2 \mathrm{NaHCO}_{3}+\mathrm{CaCl}_{2}
\end{aligned}
$$

This research used brine for carbon capture and sodium removal through the amine carrier method and the modified Solvay process. Brine would be adjusted to $\mathrm{pH} 9-14$ to precipitate magnesium hydroxide and calcium hydroxide. Magnesium hydroxide would react with saturated amine carriers to produce magnesium bicarbonate solutions. Magnesium carbonate would then be obtained by heating the amine carriers, and the amine carriers could be reused after the magnesium carbonate precipitated. The amine carriers applied in this study were 3-Amino-1-propanol, ethylamine, and diethylenetriamine. The $\mathrm{CO}_{2}$ saturated adsorption capacity of three amine carriers and the $\mathrm{CO}_{2}$ saturated adsorption capacity of an optimal amine carrier under different temperatures were surveyed in this study. After adsorbing $\mathrm{CO}_{2}$ and collecting magnesium carbonate, calcium hydroxide would be used for the modified Solvay process. As shown in Equation (2), sodium bicarbonate would be precipitated, and the precipitation rate concerned the concentration of calcium hydroxide and the contacting temperature. To realize the relationship between them, different concentrations of calcium hydroxide and temperatures of brine would be investigated. After capturing $\mathrm{CO}_{2}$ and removing sodium, the brine could be released back into the ocean, or other valuable elements such as lithium, rubidium, and cesium could be extracted without the side effect of sodium. In a nutshell, this study combines the amine carrier method and the modified Solvay process. The parameters such as the magnesium hydroxide and calcium hydroxide precipitation rate, saturated $\mathrm{CO}_{2}$ adsorption capacity of amine carriers, and sodium removal rate were discussed. The detection of magnesium carbonate through methods such as X-ray diffraction (XRD), scanning electron microscopy (SEM), and whiteness analyses were explored as well, in order to confirm its practicality. This research aims to increase the added value of brine and decrease $\mathrm{CO}_{2}$ emissions simultaneously.

\section{Experimental Section}

\subsection{Reagents and Chemicals}

Desalination brine was generated from the desalination plant in Taiwan, and its main elements and concentrations are shown in Table 2. Lithium hydroxide ( $\geq 98 \%)$ was obtained from Sigma-Aldrich (St. Louis, MO, USA) to regulate the $\mathrm{pH}$ value of brine, and magnesium hydroxide and calcium hydroxide were precipitated. 3-Amino-1propanol ( $\geq 99 \%$ ), ethylamine $(97 \%)$, and diethylenetriamine $(99 \%)$ were acquired from Sigma-Aldrich (St. Louis, MO, USA) to capture $\mathrm{CO}_{2}$ in the amine carrier method, and their chemical structures are demonstrated in Figure 1a-c. According to Figure 1, one can see that three amines are alkanolamine, alkylamine, and multi-amine, respectively. $\mathrm{CO}_{2}$ gas was procured from Yun Shan Gas Co. (Tainan, Taiwan) and combined with $\mathrm{N}_{2}$ in the ratio of 15:85. In the analysis procedure, ICP standard solution was purchased from High-Purity Standards, Inc. (North Charleston, SC, USA). The nitric acid ( $\geq 65 \%$ ) was from Sigma-Aldrich (St. Louis, MO, USA) and diluted to $1 \%$ to be the thinner for the ICP analysis. Additionally, all chemicals were analytical grade and applied without further purification. The resistivity of deionized water used in the whole process was $18.0 \mathrm{M} \Omega . \mathrm{cm}$ to avoid impurities affecting the results.

Table 2. The main elements and the concentrations of desalination brine.

\begin{tabular}{cccccccc}
\hline Elements & $\mathbf{N a}$ & $\mathbf{M g}$ & $\mathbf{K}$ & $\mathbf{C a}$ & $\mathbf{R b}$ & $\mathbf{L i}$ & $\mathbf{B}$ \\
\hline $\begin{array}{c}\text { Concentration } \\
(\mathrm{mg} / \mathrm{L})\end{array}$ & 17,420 & 2112 & 782.6 & 722.2 & 36.4 & 19.5 & 18.9 \\
\hline
\end{tabular}


<smiles>NCCCO</smiles>

(a)

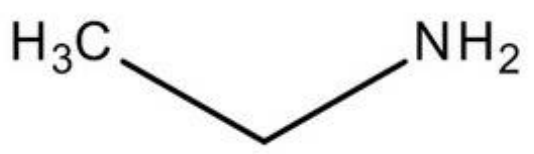

(b)<smiles>NCCNCCN</smiles>

(c)

Figure 1. The chemical structure of (a) 3-Amino-1-propanol, (b) ethylamine, and (c) diethylenetriamine.

\subsection{Apparatus}

The $\mathrm{CO}_{2}$ capture was operated through a $\mathrm{CO}_{2}$ adsorption system in the amine carrier method and modified Solvay process. The whole system is displayed in Figure 2. In this study, $2.5 \mathrm{M}$ of amine carriers $(0.5 \mathrm{~mol}$ of amine carrier was dissolved in $200 \mathrm{~mL}$ deionized water) or brine mixed with $\mathrm{Ca}(\mathrm{OH})_{2}$ were placed into the reactor. $15 \%$ of $\mathrm{CO}_{2}$ gas with $85 \%$ of $\mathrm{N}_{2}$ gas were controlled by a mass flow controller (MFC, Taiwan Puritic Corp., Hsinchu, Taiwan) before being pumped into the reactor, and MFC was able to maintain the reactor's pressure at 1 bar. After being pumped into the reactor, a temperature controller (XMtd-204; BaltaLab, Vidzemes priekšpilsēta, Rīga, Latvia) maintained the temperature in the process. When the reaction finished, there were a gas analyzer and computer to analyze the $\mathrm{CO}_{2}$ concentration of effluent gas and make us calculate the $\mathrm{CO}_{2}$ adsorption capacity in the form of $\mathrm{L} \mathrm{CO}_{2} / \mathrm{mol}$ amine and $\mathrm{L} \mathrm{CO}_{2} / \mathrm{L}$ brine (Equations (3) and (4)). The adsorption process was terminated when the analyzer detected that the $\mathrm{CO}_{2}$ concentration of effluent gas was $15 \%$. This reveals that the amine carriers and brine could no longer adsorb $\mathrm{CO}_{2}$. Besides, the gas was transmitted by the PTFE pipes during this whole experiment to secure no gas emissions.

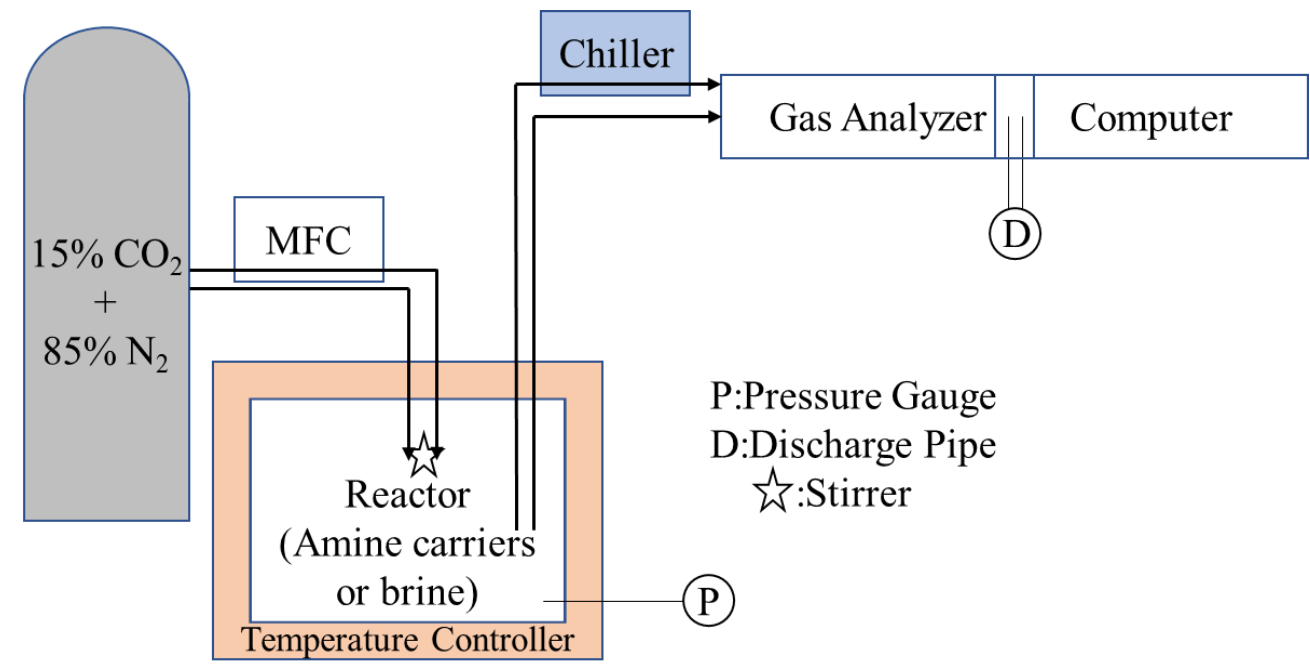

Figure 2. The $\mathrm{CO}_{2}$ adsorption system in this study. 
After magnesium hydroxide reacted with saturated amine carriers, magnesium carbonate was analyzed by X-ray diffraction (XRD, DX-2700, Dandong City, Liaoning Province, China) and scanning electron microscopy (SEM, S-3000N, Hitachi, Tokyo, Japan). The magnesium, calcium, and sodium precipitation efficiencies were detected by inductively coupled plasma optical emission spectrometry (ICP-OES, Varian, Vista-MPX, PerkinElmer, Waltham, MA, USA). On the other hand, the whiteness of magnesium carbonate was detected by a whiteness meter (Pora Volo-W, JIN-BOMB Enterprise Co., Ltd., Kaohsiung, Taiwan) to confirm its applied value.

$$
\begin{gathered}
\mathrm{CO}_{2} \text { adsorption capacity }\left(\frac{\mathrm{LCO}_{2}}{\text { mol Amine }}\right)=\frac{\Sigma \mathrm{LCO}_{2 \text { capture }}}{\text { mol Amine }} \\
\mathrm{CO}_{2} \text { adsorption capacity }\left(\frac{\mathrm{L} \mathrm{CO}}{\mathrm{L} \text { Brine }}\right)=\frac{\Sigma \mathrm{L} \mathrm{CO} 2 \text { capture }}{\mathrm{L} \text { Brine }}
\end{gathered}
$$

\section{Results and Discussion}

\subsection{The Recovery Rate of Magnesium Hydroxide and Calcium Hydroxide}

At the beginning of the experiment, lithium hydroxide was added into the brine to precipitate magnesium hydroxide and calcium hydroxide under the condition of $298 \mathrm{~K}$ and $10 \mathrm{~min}$. The original $\mathrm{pH}$ value of brine was 8.14 , so the parameters were set up from $\mathrm{pH} 9$ to $\mathrm{pH}$ 14. The precipitation efficiency was calculated as Equation (5), and the precipitation rates of magnesium and calcium at different $\mathrm{pH}$ values are shown in Figure 3. As Figure 3 reveals, magnesium could be precipitated as the $\mathrm{pH}$ value of the solution increased from 9 to 12 , and the precipitation rate of magnesium hydroxide was $99.94 \%(2112 \mathrm{mg} / \mathrm{L}$ to $1.175 \mathrm{mg} / \mathrm{L}$ ). On the other hand, calcium hydroxide was mainly precipitated at $\mathrm{pH} 14$, and the precipitation rate was $97.2 \%$ ( $722.16 \mathrm{mg} / \mathrm{L}$ to $19.57 \mathrm{mg} / \mathrm{L})$. The precipitated magnesium hydroxide and calcium hydroxide were then applied to the amine carrier method and modified Solvay process, respectively.

$$
\mathrm{P}(\%)=\frac{[\mathrm{M}]_{0}-[\mathrm{M}]}{[\mathrm{M}]_{0}} \cdot 100
$$

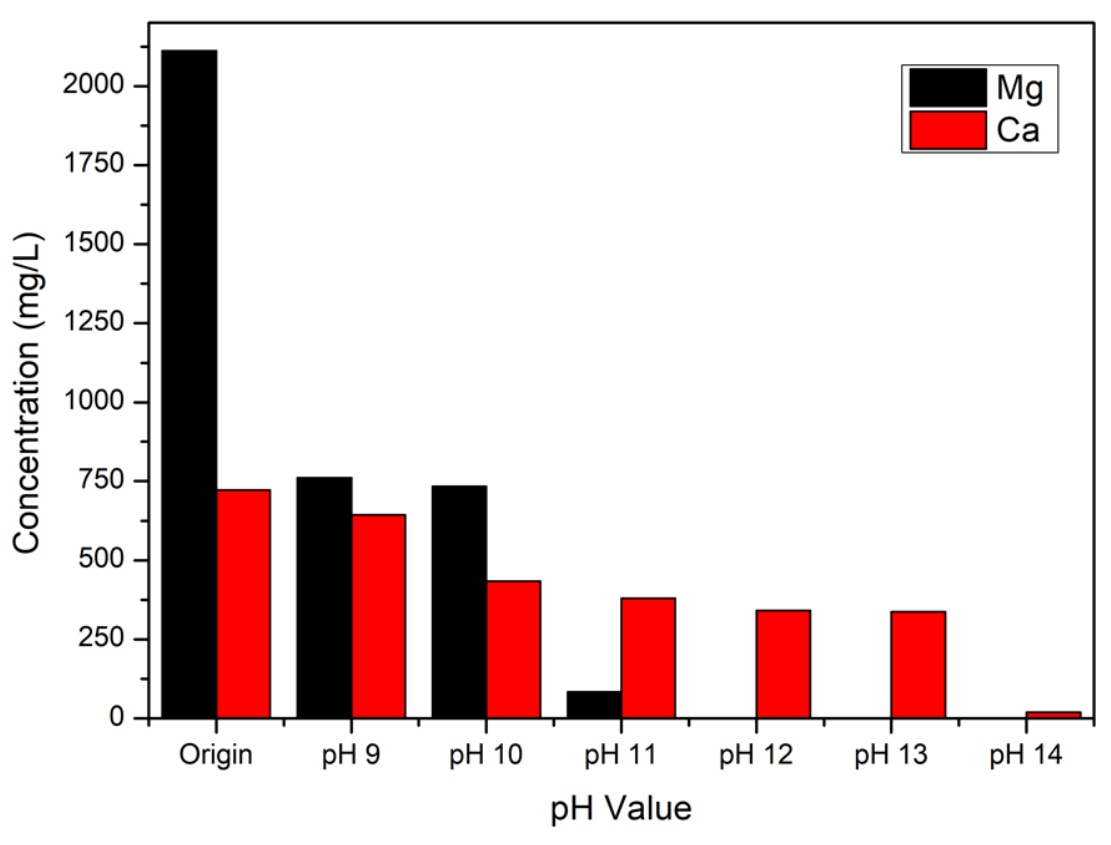

Figure 3. Precipitation efficiencies of magnesium hydroxide and calcium hydroxide. 
$\mathrm{P}$ is the precipitation efficiency, $[\mathrm{M}]_{0}$ is the metal (Mg and Ca) concentration of brine, and $[\mathrm{M}]$ is the metal concentration $(\mathrm{Mg}$ and $\mathrm{Ca}$ ) of brine after the precipitation process.

\subsection{Amine Carrier Method- $\mathrm{CO}_{2}$ Adsorption Capacities of Different Amine Carriers}

Before magnesium hydroxide reacted with saturated amine carriers, the adsorption capacities of different amine carriers should be explored first. Figure $4 \mathrm{a}-\mathrm{c}$ reveals the saturated $\mathrm{CO}_{2}$ adsorption capacities of 3-Amino-1-propanol, ethylamine, and diethylenetriamine under the condition of $288 \mathrm{~K}$. In Figure 4, the trends of the three amine carriers are similar. The $\mathrm{CO}_{2}$ adsorption capacities rose when time increased. However, their saturated capacities and time were totally different. Their saturated $\mathrm{CO}_{2}$ adsorption capacities were $15.1 \mathrm{~L}, 9 \mathrm{~L}$, and $15.2 \mathrm{~L}$ per mol amines at about $150 \mathrm{~min}, 50 \mathrm{~min}$, and $300 \mathrm{~min}$, respectively. The $\mathrm{CO}_{2}$ adsorption capacities were affected by the ethyl group, so the saturated capacities were highest when using diethylenetriamine in this experiment. However, the stability of diethylenetriamine was dependent on the number of amino groups [34]. Its viscosity might enlarge when $\mathrm{CO}_{2}$ was dissolved. The enlarged viscosity made the reaction challenging to conduct, so the period of the experiment was most extended among the three amine carriers.

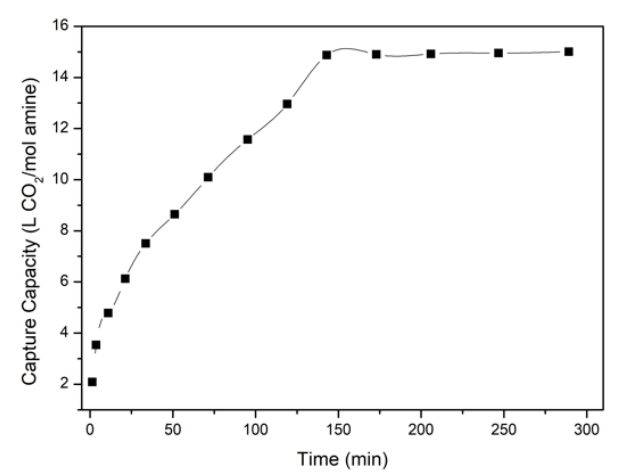

(a)

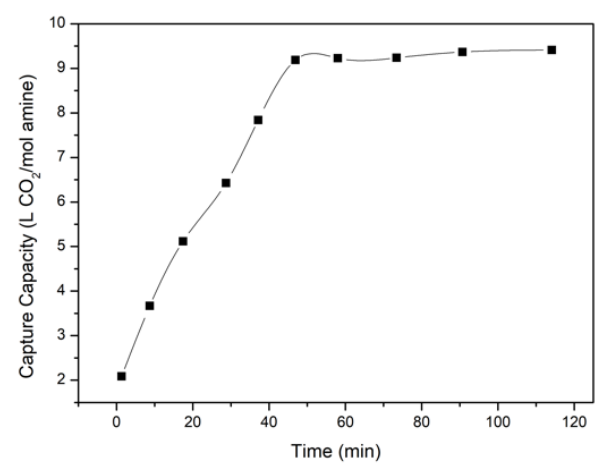

(b)

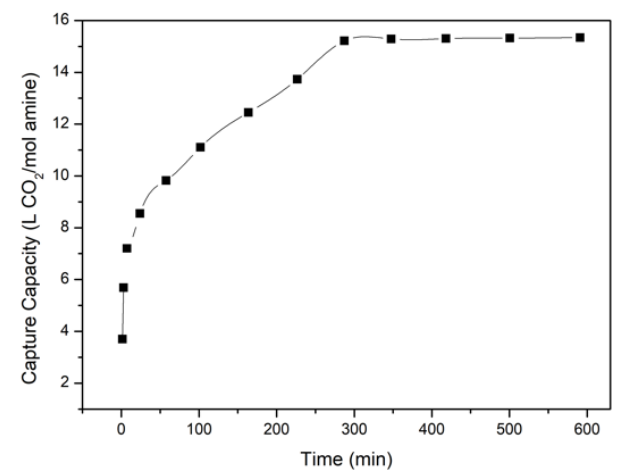

(c)

Figure 4. The saturated $\mathrm{CO}_{2}$ adsorption capacities of (a) 3-Amino-1-propanol, (b) ethylamine, and (c) diethylenetriamine.

Although the reacting time of ethylamine was shorter and the adsorption capacity of diethylenetriamine was higher in this research, ethylamine and diethylenetriamine are more volatile than 3-Amino-1-propanol (Ethylamine and diethylenetriamine would produce fogs). Besides, it was also found that the temperature of diethylenetriamine during the adsorbing process would increase and enhance the temperature controller's energy consumption. For the sake of more carbon dioxide, safety, and a lower energy consumption, 3-Amino-1-propanol was chosen as the optimal amine carrier in this study. 


\subsection{Amine Carrier Method-CO $\mathrm{CO}_{2}$ Adsorption Capacities of 3-Amino-1-Propanol at Different Temperatures}

The temperatures of 3-Amino-1-propanol were set up from $288 \mathrm{~K}$ to $328 \mathrm{~K}$ in this part, and the concentration of 3-Amino-1-propanol was $2.5 \mathrm{M}$. Figure 5 illustrates that lower temperatures of 3-Amino-1-propanol could capture more $\mathrm{CO}_{2}$. At $288 \mathrm{~K}$ and 298 $\mathrm{K}, 15 \mathrm{~L}$ and $11 \mathrm{~L}$ of $\mathrm{CO}_{2}$ could be adsorbed by $1 \mathrm{~mol}$ of 3-Amino-1-propanol, separately. However, when the temperature reached $328 \mathrm{~K}$, 3-Amino-1-propanol only captured $9.7 \mathrm{~L}$ of $\mathrm{CO}_{2}$. The speculated reason for this is that the solubility of $\mathrm{CO}_{2}$ was lower under the condition of higher temperatures and that 3-Amino-1-propanol would evaporate at higher temperatures as well. In this case, 3-Amino-1-propanol could not adsorb $\mathrm{CO}_{2}$ efficiently then. Combining the results of the two parts, $288 \mathrm{~K}$ of 3-Amino-1-propanol was optimal, and it could adsorb about $15 \mathrm{~L}$ of $\mathrm{CO}_{2}$.

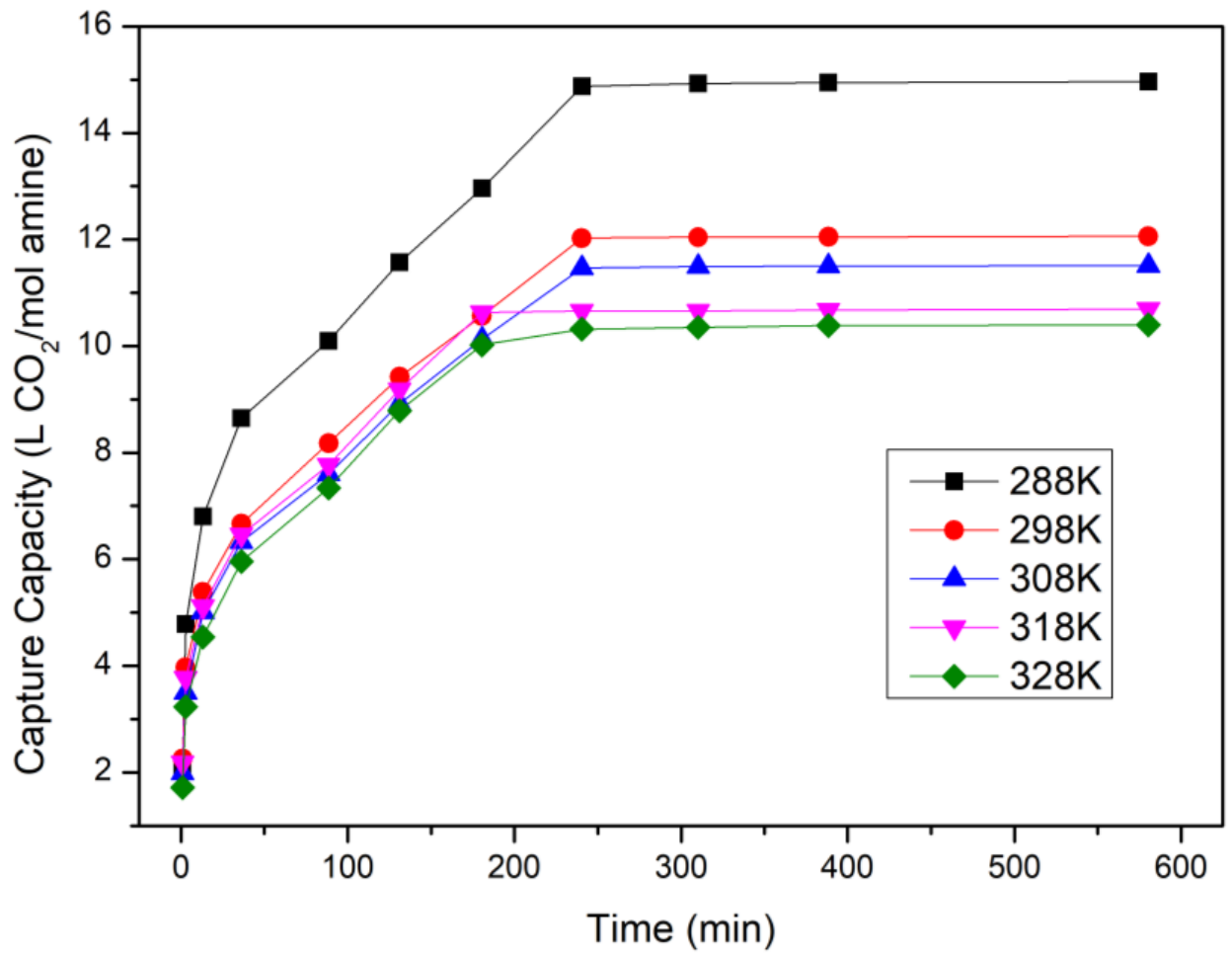

Figure 5. Saturated $\mathrm{CO}_{2}$ capacity of 3-Amino-1-propanol at different temperatures.

\subsection{XRD, SEM, and Whiteness Analyses of Magnesium Carbonate}

After capturing $\mathrm{CO}_{2}$ through 3-Amino-1-propanol at $288 \mathrm{~K}$, moderate magnesium hydroxide from desalination brine was added into saturated 3-Amino-1-propanol. Magnesium hydroxide would then react with $\mathrm{CO}_{2}$ and turn into magnesium bicarbonate solutions. Through heating the amine carriers, magnesium carbonate would be precipitated, and the amine carriers could be reused. The XRD pattern of magnesium carbonate is displayed in Figure 6, and the magnesium carbonate was in the form of nesquehonite. The molecular formula and crystal system of nesquehonite are $\mathrm{MgCO}_{3} \cdot 3 \mathrm{H}_{2} \mathrm{O}$ and monoclinic [38-41]. To gain a deeper understanding of nesquehonite, the SEM analysis is revealed in Figure 7. The shape of nesquehonite was linear and acicular, and it coincided with the narrative in the other literature [41]. 


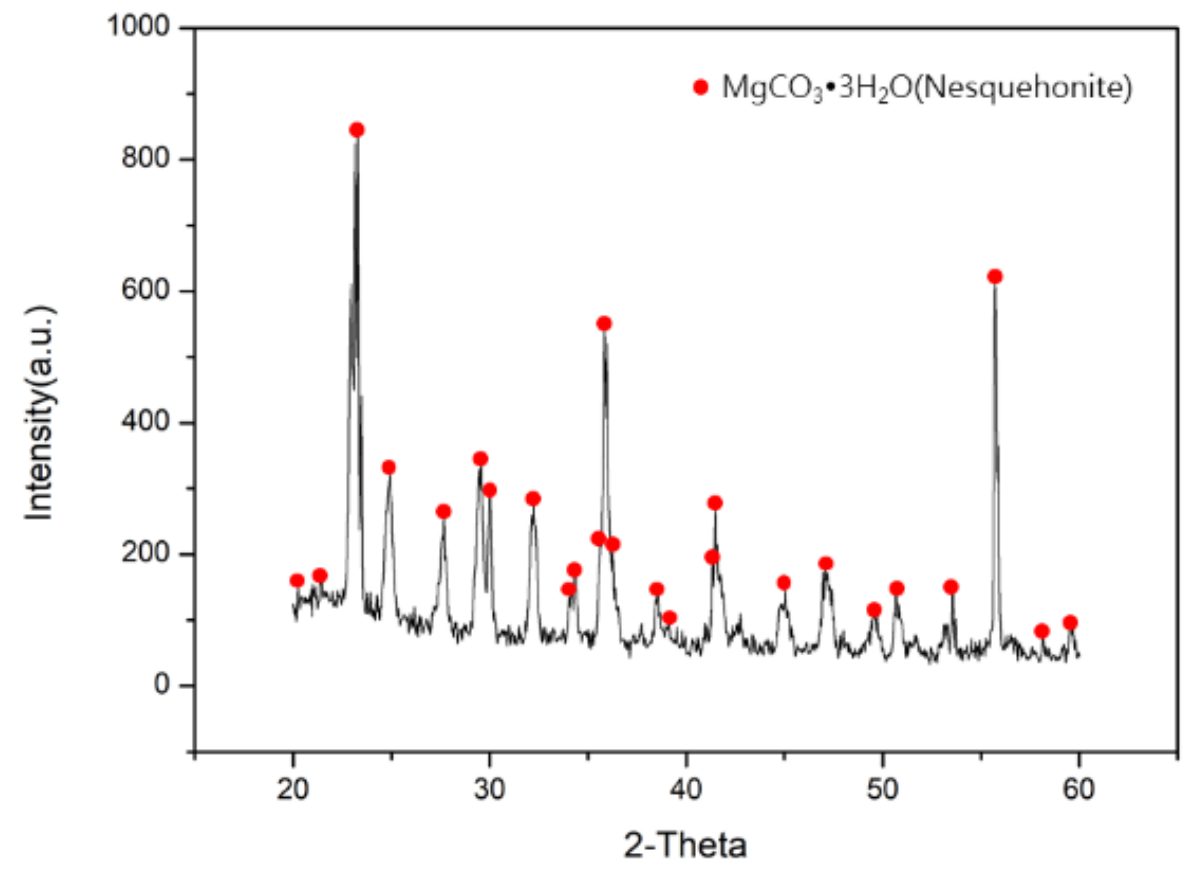

Figure 6. XRD analysis of magnesium carbonate.

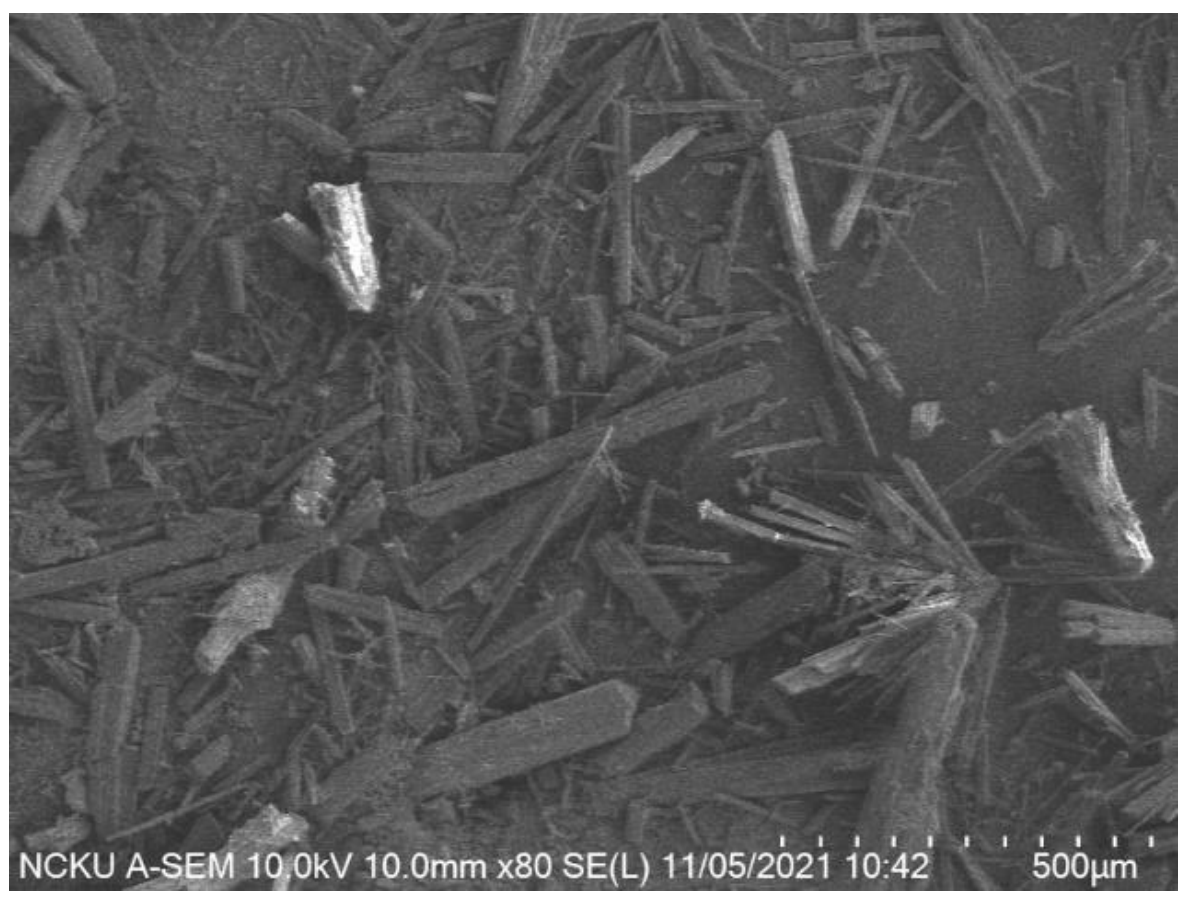

Figure 7. SEM analysis of magnesium carbonate (nesquehonite).

On the other hand, magnesium carbonate can be used as the coating material, and its index is whiteness. Whiteness is the degree of whiteness on the surface of a substance. If the whiteness is above 90 , it can be the coating material or the paint ingredient. A comparison of the whiteness of commercial and experimental magnesium carbonate is shown in Table 3. To get a higher preciseness, three different samples of commercial and experimental magnesium carbonate were detected, and the average whiteness of commercial product and magnesium carbonate we obtained was 94.8 and 93.6, respectively. This means that the magnesium carbonate produced in this study has an applied value in other industries so as to reach resources' circulation. 
Table 3. Whiteness of commercial product and experimental magnesium carbonate.

\begin{tabular}{ccc}
\hline Magnesium Carbonate & Samples & Whiteness \\
\hline \multirow{2}{*}{ Commercial product } & Sample 1 & 94.9 \\
& Sample 2 & 94.7 \\
& Sample 3 & 94.8 \\
\hline \multirow{2}{*}{ Experimental magnesium carbonate } & Sample 1 & 93.5 \\
& Sample 2 & 93.5 \\
& Sample 3 & 93.8 \\
\hline
\end{tabular}

\subsection{Modified Solvay Process-Removal of Sodium at Different $\mathrm{Ca}(\mathrm{OH})_{2}$ Concentrations}

After finishing the amine carrier method, the modified Solvay process was implemented through calcium hydroxide and desalination brine. This process could not only adsorb $\mathrm{CO}_{2}$ but also remove the sodium in the brine. The procedure was as follows: calcium hydroxide was added into $\mathrm{pH} 14$ of brine and reacted as in Equation (2). The concentrations of $\mathrm{Ca}(\mathrm{OH})_{2}$ were set up from $5 \mathrm{~g} / \mathrm{L}$ to $25 \mathrm{~g} / \mathrm{L}$, and the results are demonstrated in Figure 8. As Figure 8 illustrates, $5 \mathrm{~g} / \mathrm{L}$ of $\mathrm{Ca}(\mathrm{OH})_{2}$ could only remove $1000 \mathrm{ppm}$ of sodium, and the value would increase with the $\mathrm{Ca}(\mathrm{OH})_{2}$ concentration increasing. Under the condition of $25 \mathrm{~g} / \mathrm{L}$ of $\mathrm{Ca}(\mathrm{OH})_{2}$, the sodium removal could reach about $7000 \mathrm{ppm}$, and the removal efficiency was $45 \%$. The results seem to show that the concentration of $\mathrm{Ca}(\mathrm{OH})_{2}$ could increase continuously; however, excessive $\mathrm{Ca}(\mathrm{OH})_{2}$ would react with $\mathrm{CO}_{2}$ first and produce calcium carbonate rather than sodium bicarbonate (It would interrupt the generation of sodium bicarbonate). Therefore, the optimal $\mathrm{Ca}(\mathrm{OH})_{2}$ concentration in this study was $25 \mathrm{~g} / \mathrm{L}$.

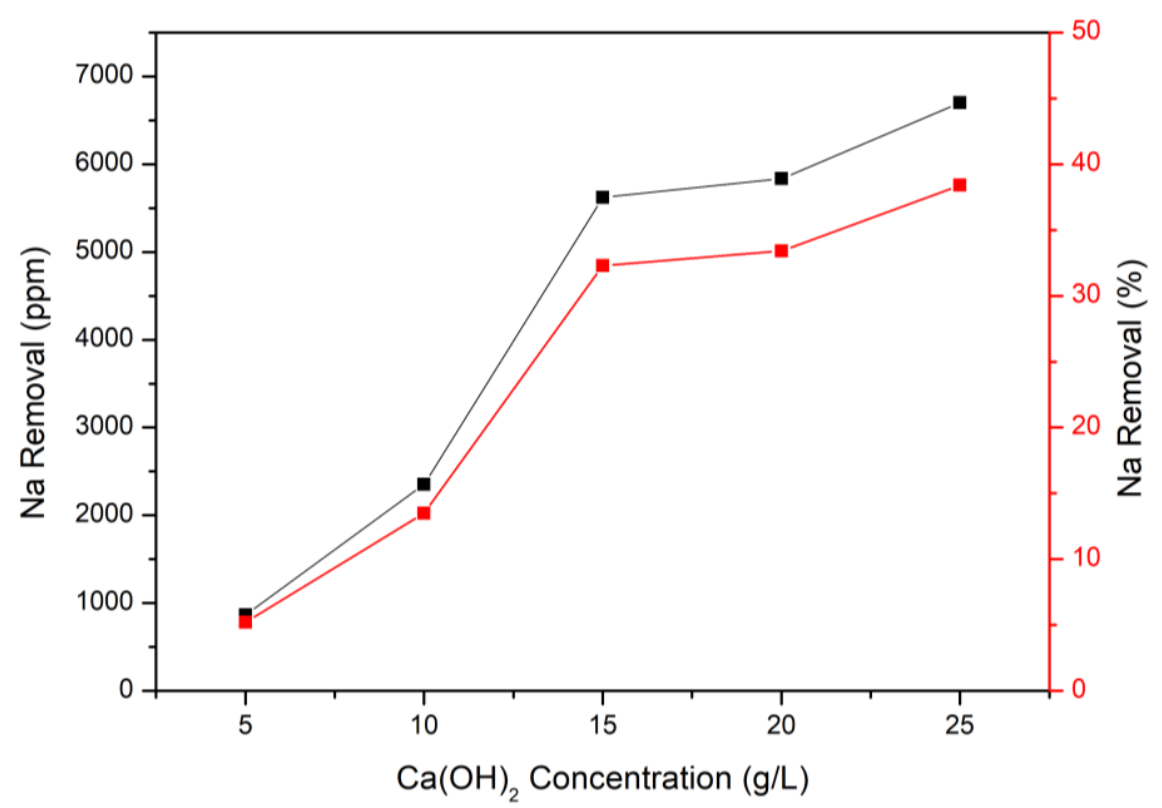

Figure 8. Removal of sodium at different $\mathrm{Ca}(\mathrm{OH})_{2}$ concentrations through modified Solvay process.

\subsection{Modified Solvay Process-Removal of Sodium at Different Temperatures}

The temperatures were set up from $288 \mathrm{~K}$ to $328 \mathrm{~K}$ in this study, and the fixed parameter was $25 \mathrm{~g} / \mathrm{L}$ of calcium hydroxide. Figure 9 illustrates that an increase in the temperatures would decrease the removal efficiency of sodium. At $288 \mathrm{~K}$, the sodium removal was about $7000 \mathrm{ppm}$, and it was only under $1000 \mathrm{ppm}$ at $328 \mathrm{~K}$. The main reasons were the solubilities of $\mathrm{CO}_{2}$ and sodium bicarbonate. At higher temperatures, the solubility of $\mathrm{CO}_{2}$ would decrease and make it challenging to conduct the reaction. On the other hand, even if the reaction progressed, the precipitated sodium bicarbonate was easily dissolved in the high-temperature aqueous solution [36] (The solubilities of sodium bicarbonate at 
different temperatures are demonstrated in Table 4). Combining the above reasons, $25 \mathrm{~g} / \mathrm{L}$ of $\mathrm{Ca}(\mathrm{OH})_{2}$ at $288 \mathrm{~K}$ was the optimal parameter for removing sodium. After removing sodium, the brine could then be released back into the ocean, or other valuable metals could be extracted in a further process. Sodium bicarbonate can be used in other industries as well in order to achieve the goal of a circular economy. In a nutshell, the modified Solvay process could adsorb $16 \mathrm{~L}$ of $\mathrm{CO}_{2}$ per liter of brine with $25 \mathrm{~g}$ of $\mathrm{Ca}(\mathrm{OH})_{2}$ and reduce the side effect of sodium.

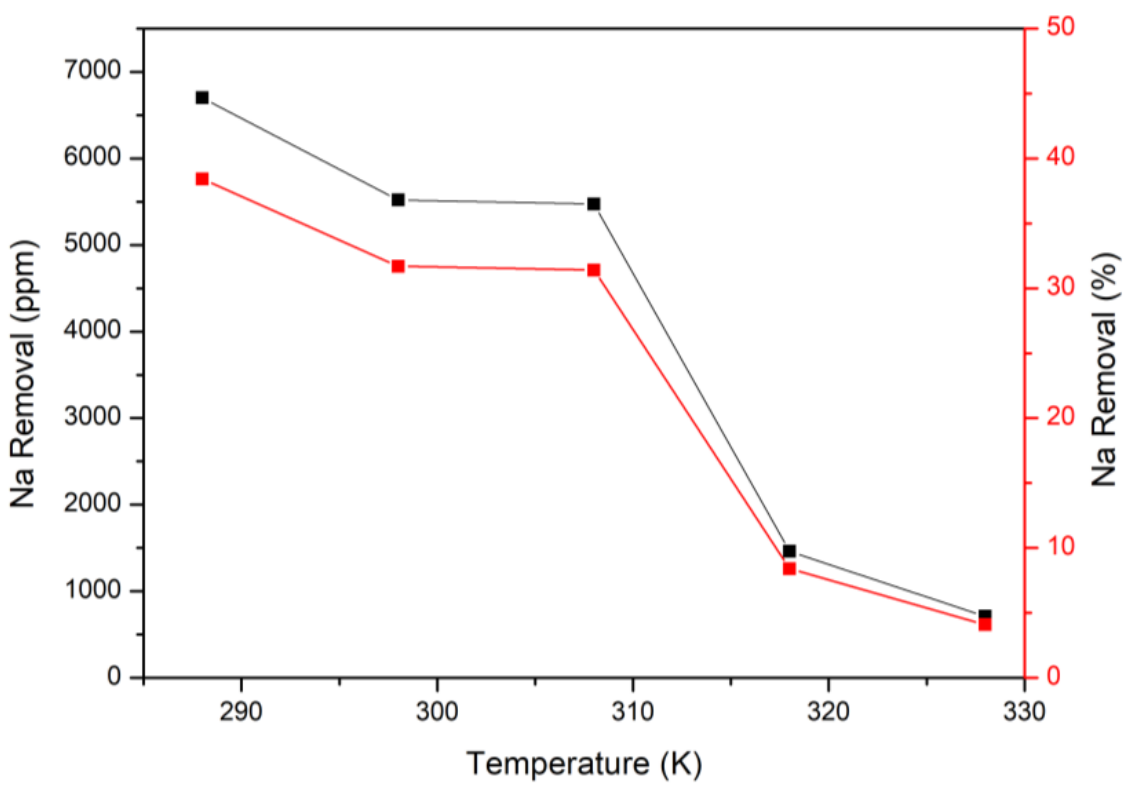

Figure 9. Removal of sodium at different temperatures through the modified Solvay process.

Table 4. Solubility of sodium bicarbonate at different temperatures.

\begin{tabular}{cccccc}
\hline Temperatures & $288 \mathrm{~K}$ & $298 \mathrm{~K}$ & $308 \mathrm{~K}$ & $318 \mathrm{~K}$ & $328 \mathrm{~K}$ \\
\hline Solubility (g/100 g water) & 7.6 & 8.4 & 9.9 & 12.1 & 13.9 \\
\hline
\end{tabular}

\section{Conclusions}

This study aims to recover magnesium and calcium to adsorb $\mathrm{CO}_{2}$ and remove sodium through the amine carrier method and the modified Solvay process. The results reveal that the magnesium hydroxide and calcium hydroxide precipitation rates were $99.94 \%$ and

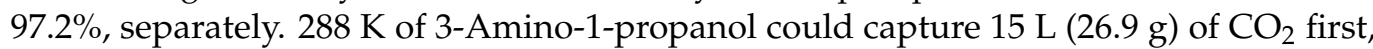
and magnesium hydroxide could then react with 3-Amino-1-propanol in order to turn into magnesium carbonate. The XRD, SEM, and whiteness analyses of magnesium carbonate showed that it had an applied value in this study as well. Moreover, $25 \mathrm{~g} / \mathrm{L}$ of $\mathrm{Ca}(\mathrm{OH})_{2}$ at $288 \mathrm{~K}$ was the optimal parameter for removing sodium and adsorbing $\mathrm{CO}_{2}$ in the modified Solvay process. The efficiencies of sodium removal and capacity of $\mathrm{CO}_{2}$ were $7000 \mathrm{ppm}$ $(45 \%)$ and $16 \mathrm{~L}(28.7 \mathrm{~g})$, respectively. In sum, this research demonstrates a system that could capture $\mathrm{CO}_{2}$ through amine carriers and brine. In addition, the high concentration of sodium in the brine was also decreased. This means that the study could reduce $\mathrm{CO}_{2}$ emissions and the environmental problems caused by brine simultaneously.

Author Contributions: Conceptualization, C.-H.L. and P.-H.C.; methodology, C.-H.L. and W.-S.C.; validation, C.-H.L., P.-H.C. and W.-S.C.; formal analysis, C.-H.L.; investigation, C.-H.L.; data curation, C.-H.L. and P.-H.C.; writing-original draft preparation, C.-H.L.; writing-review and editing, C.H.L.; visualization, C.-H.L.; supervision, W.-S.C. All authors have read and agreed to the published version of the manuscript.

Funding: This research received no external funding. 
Acknowledgments: This work was supported by the Laboratory of Resource Circulation in the Dept. of Resources Engineering, National Cheng-Kung University.

Conflicts of Interest: The authors declare no conflict of interest.

\section{References}

1. Visser, P.M.; Verspagen, J.M.; Sandrini, G.; Stal, L.J.; Matthijs, H.C.; Davis, T.W.; Paerl, H.W.; Huisman, J. How rising CO 2 and global warming may stimulate harmful cyanobacterial blooms. Harmful Algae 2016, 54, 145-159. [CrossRef] [PubMed]

2. Lee, Z.H.; Sethupathi, S.; Lee, K.T.; Bhatia, S.; Mohamed, A.R. An overview on global warming in Southeast Asia: $\mathrm{CO}_{2}$ emission status, efforts done, and barriers. Renew. Sustain. Energy Rev. 2013, 28, 71-81. [CrossRef]

3. Yoro, K.O.; Daramola, M.O. $\mathrm{CO}_{2}$ emission sources, greenhouse gases, and the global warming effect. In Advances in Carbon Capture; Elsevier: Amsterdam, The Netherlands, 2020; pp. 3-28.

4. Rosa, L.P.; Ribeiro, S.K. The present, past, and future contributions to global warming of $\mathrm{CO}_{2}$ emissions from fuels. Clim. Chang. 2001, 48, 289-307. [CrossRef]

5. $\quad$ Philander, S.G. Encyclopedia of Global Warming and Climate Change: AE; Sage: Thousand Oaks, CA, USA, 2008.

6. Mejía, A.; Nucete Hubner, M.; Ron Sánchez, E.; Doria, M. The United Nations World Water Development Report-No 4-Water and Sustainability (A Review of Targets, Tools and Regional Cases); United Nations: San Francisco, CA, USA, 2012.

7. Wagnick, K. IDA Worldwide Desalting Plants: Inventory Report No, 17; Wangnick Consulting: Gnarrenburg, Germany, 2002.

8. Kim, I.; Yoo, Y.; Son, J.; Park, J.; Huh, I.-S.; Kang, D. Two-step mineral carbonation using seawater-based industrial wastewater: An eco-friendly carbon capture, utilization, and storage process. J. Mater. Cycles Waste Manag. 2020, 22, 333-347. [CrossRef]

9. Kang, D.; Lee, M.-G.; Jo, H.; Yoo, Y.; Lee, S.-Y.; Park, J. Carbon capture and utilization using industrial wastewater under ambient conditions. Chem. Eng. J. 2017, 308, 1073-1080. [CrossRef]

10. Al-Mamoori, A.; Krishnamurthy, A.; Rownaghi, A.A.; Rezaei, F. Carbon Capture and Utilization Update. Energy Technol. 2017, 5, 834-849. [CrossRef]

11. Stünkel, S.; Drescher, A.; Wind, J.; Brinkmann, T.; Repke, J.-U.; Wozny, G. Carbon dioxide capture for the oxidative coupling of methane process-A case study in mini-plant scale. Chem. Eng. Res. Des. 2011, 89, 1261-1270. [CrossRef]

12. Yeh, A.C.; Bai, H. Comparison of ammonia and monoethanolamine solvents to reduce $\mathrm{CO}_{2}$ greenhouse gas emissions. Sci. Total Environ. 1999, 228, 121-133. [CrossRef]

13. Bai, H.; Yeh, A.C. Removal of $\mathrm{CO}_{2}$ Greenhouse Gas by Ammonia Scrubbing. Ind. Eng. Chem. Res. 1997, 36, 2490-2493. [CrossRef]

14. Diao, Y.-F.; Zheng, X.-Y.; He, B.; Chen, C.-H.; Xu, X.-C. Experimental study on capturing $\mathrm{CO}_{2}$ greenhouse gas by ammonia scrubbing. Energy Convers. Manag. 2004, 45, 2283-2296. [CrossRef]

15. Li, X.; Hagaman, E.; Tsouris, A.C.; Lee, J.W. Removal of Carbon Dioxide from Flue Gas by Ammonia Carbonation in the Gas Phase. Energy Fuels 2002, 17, 69-74. [CrossRef]

16. Pan, S.-Y.; Chang, E.; Chiang, P.-C. $\mathrm{CO}_{2}$ Capture by Accelerated Carbonation of Alkaline Wastes: A Review on Its Principles and Applications. Aerosol Air Qual. Res. 2012, 12, 770-791. [CrossRef]

17. Li, Y.; Liu, C.; Sun, R.; Liu, H.; Wu, S.; Lu, C. Sequential $\mathrm{SO}_{2} / \mathrm{CO}_{2}$ capture of calcium-based solid waste from the paper industry in the calcium looping process. Ind. Eng. Chem. Res. 2012, 51, 16042-16048. [CrossRef]

18. Karimi, M.; de Tuesta, J.L.D.; Gonçalves, C.N.D.P.; Gomes, H.T.; Rodrigues, A.E.; Silva, J.A.C.; Mohsen, K.; José, A.S. Compost from Municipal Solid Wastes as a Source of Biochar for $\mathrm{CO}_{2}$ Capture. Chem. Eng. Technol. 2020, 43, 1336-1349. [CrossRef]

19. Ibrahim, M.H.; El-Naas, M.H.; Zevenhoven, R.; Al-Sobhi, S.A. Enhanced $\mathrm{CO}_{2}$ capture through reaction with steel-making dust in high salinity water. Int. J. Greenh. Gas Control 2019, 91, 102819. [CrossRef]

20. Olivares-Marín, M.; Maroto-Valer, M.M. Development of adsorbents for $\mathrm{CO}_{2}$ capture from waste materials: A review. Greenh Gases Sci. Technol. 2012, 2, 20-35. [CrossRef]

21. Kaithwas, A.; Prasad, M.; Kulshreshtha, A.; Verma, S. Industrial wastes derived solid adsorbents for $\mathrm{CO}_{2}$ capture: A mini review. Chem. Eng. Res. Des. 2012, 90, 1632-1641. [CrossRef]

22. Pour, N.; Webley, P.; Cook, P.J. Potential for using municipal solid waste as a resource for bioenergy with carbon capture and storage (BECCS). Int. J. Greenh. Gas Control 2018, 68, 1-15. [CrossRef]

23. Ohenoja, K.; Rissanen, J.; Kinnunen, P.; Illikainen, M. Direct carbonation of peat-wood fly ash for carbon capture and utilization in construction application. J. CO2 Util. 2020, 40, 101203. [CrossRef]

24. Dindi, A.; Quang, D.V.; Vega, L.F.; Nashef, E.; Abu-Zahra, M.R. Applications of fly ash for $\mathrm{CO}_{2}$ capture, utilization, and storage. J. CO2 Util. 2018, 29, 82-102. [CrossRef]

25. Mankar, J.S.; Rayalu, S.S.; Balasubramanian, R.; Krupadam, R.J. High performance $\mathrm{CO}_{2}$ capture at elevated temperatures by using cenospheres prepared from solid waste, fly ash. Chemosphere 2021, 284, 131405. [CrossRef]

26. Sreenivasulu, B.; Sreedhar, I.; Reddy, B.M.; Raghavan, K.V. Stability and Carbon Capture Enhancement by Coal-Fly-Ash-Doped Sorbents at a High Temperature. Energy Fuels 2017, 31, 785-794. [CrossRef]

27. Skocek, J.; Zajac, M.; Ben Haha, M. Carbon Capture and Utilization by mineralization of cement pastes derived from recycled concrete. Sci. Rep. 2020, 10, 1-12.

28. Lu, L.; Guest, J.S.; Peters, C.A.; Zhu, X.; Rau, G.H.; Ren, Z.J. Wastewater treatment for carbon capture and utilization. Nat. Sustain. 2018, 1, 750-758. [CrossRef] 
29. Dong, C.; Huang, G.; Cheng, G.; An, C.; Yao, Y.; Chen, X.; Chen, J. Wastewater treatment in amine-based carbon capture. Chemosphere 2019, 222, 742-756. [CrossRef] [PubMed]

30. Mustafa, J.; Aya, A.-H.M.; Al-Marzouqi, A.H.; El-Naas, M.H. Simultaneous treatment of reject brine and capture of carbon dioxide: A comprehensive review. Desalination 2020, 483, 114386. [CrossRef]

31. Galvez-Martos, J.-L.; Elhoweris, A.; Morrison, J.; Al-Horr, Y. Conceptual design of a $\mathrm{CO}_{2}$ capture and utilisation process based on calcium and magnesium rich brines. J. CO2 Util. 2018, 27, 161-169. [CrossRef]

32. El-Naas, M.H.; Al-Marzouqi, A.H.; Chaalal, O. A combined approach for the management of desalination reject brine and capture of $\mathrm{CO}_{2}$. Desalination 2010, 251,70-74. [CrossRef]

33. Kang, D.; Jo, H.; Lee, M.-G.; Park, J. Carbon dioxide utilization using a pretreated brine solution at normal temperature and pressure. Chem. Eng. J. 2016, 284, 1270-1278. [CrossRef]

34. Yoo, Y.; Kang, D.; Park, S.; Park, J. Carbon utilization based on post-treatment of desalinated reject brine and effect of structural properties of amines for $\mathrm{CaCO}_{3}$ polymorphs control. Desalination 2020, 479, 114325. [CrossRef]

35. Dindi, A.; Quang, D.V.; Abu Zahra, M. Simultaneous carbon dioxide capture and utilization using thermal desalination reject brine. Appl. Energy 2015, 154, 298-308. [CrossRef]

36. El-Naas, M.H.; Mohammad, A.F.; Suleiman, M.I.; Al Musharfy, M.; Al-Marzouqi, A.H. A new process for the capture of $\mathrm{CO}_{2}$ and reduction of water salinity. Desalination 2017, 411, 69-75. [CrossRef]

37. Carson, P.A. Hazardous Chemicals Handbook; Elsevier: Amsterdam, The Netherlands, 2002.

38. Montes-Hernandez, G.; Bah, M.; Renard, F. Mechanism of formation of engineered magnesite: A useful mineral to mitigate $\mathrm{CO}_{2}$ industrial emissions. J. CO2 Util. 2019, 35, 272-276. [CrossRef]

39. Unluer, C.; Al-Tabbaa, A. Green construction with carbonating reactive magnesia porous blocks: Effect of cement and water contents. In Proceedings of the International Conference on Future Concrete, Dubai, United Arab Emirates, 12-14 December 2011.

40. Yan, P.K.; Wang, B.; Gao, Y.J. Study on Synthesis of the High Aspect Ratios Nesquehonite Whiskers. Adv. Mater. Res. 2011, 239, 1118-1122. [CrossRef]

41. Stephan, G.; MacGillavry, C.H. The crystal structure of nesquehonite, $\mathrm{MgCO}_{3} \cdot 3 \mathrm{H}_{2} \mathrm{O}$. Acta Crystallogr. Sect. B 1972, $28,1031-1033$. [CrossRef] 